\title{
THE NATIVE LADY'S-SLIPPER ORCHIDS OF SASKATCHEWAN
}

\author{
by VERNON L. HARMS*
}

Among the most beautiful and inresting wildflowers of Saskatchewan re the various species of Lady'slipper Orchids. These, with the alypso Orchid, represent the largest lowered native orchids in Saskathewan, where most members of the rchid family have relatively small, inonspicuous flowers. As all orchids, he lady's-slipper flower is epigynous ith the sepals and petals arising bove the inferior ovary (Figure 1). the two fertile stamens are attached $n$ either side of a petal-like sterile tamen (staminodium) and all are ised to the style to form a column ith the two anthers on either side elow the stigma. The three petals inlude two slender, lateral petals and a wer petal called the lip which is lodified into a pouch-like structure. lthough three sepals are basically resent, in most lady's-slipper species he two lower ones are more or less ised to form what appears to be only vo sepals: an upper and a lower one Figure 1).

There are four native species of dy's-slippers known from Saskathewan: the Yellow Lady's-slipper Cypripedium calceolus var. pubescens), he Stemless Lady's-slipper Fypripedium acaule), the Northern ady's-slipper

(Cypripedium isserinum), and the Ram's-head ady's-slipper

(Cypripedium ietinum). Of these, the latter three pecies are quite rare in their ocurrence, and only the Yellow Lady'sipper is relatively frequent. But even

raser Herbarium,

hiversity of Saskatchewan,

skatoon, Sask. the Yellow Lady's-slipper is hardly abundant anywhere in the province.

The rarity of these lady's-slippers greatly enhances interest in their discovery. A primary reason for publishing this article on the lady'sslippers is to encourage wildflower enthusiasts and nature lovers in the province to be more aware of these orchids and locate new records for them. However, because of the rarity of these orchids, they should not actually be collected. Successful transplanting to local gardens nearly always fails because of the special requirements of the plants. Good photographs are very desirable, especially if in colour. Anyone finding these orchids will perform a valuable service if they record the exact locality and forward this information to us at the Fraser Herbarium, University of Saskatchewan, Saskatoon, or to any other recognized herbarium. If there seems good reason to collect a voucher specimen, a botanist from the herbarium will go and carefully collect what is necessary, prepare and file it properly in order to authenticate the record without endangering the perpetuation of a local colony of these orchids.

The following identification key can be used to determine the different species of lady's-slippers. Such a key is quite simple to use. The user is first confronted with a choice between the number one leads. If the characters of the unknown plant fit the first lead, the plant is identified as the Stemless Lady's-slipper. If, instead, the characters of the unknown plant fit the second of the number one leads, the user goes on to the choice between the 


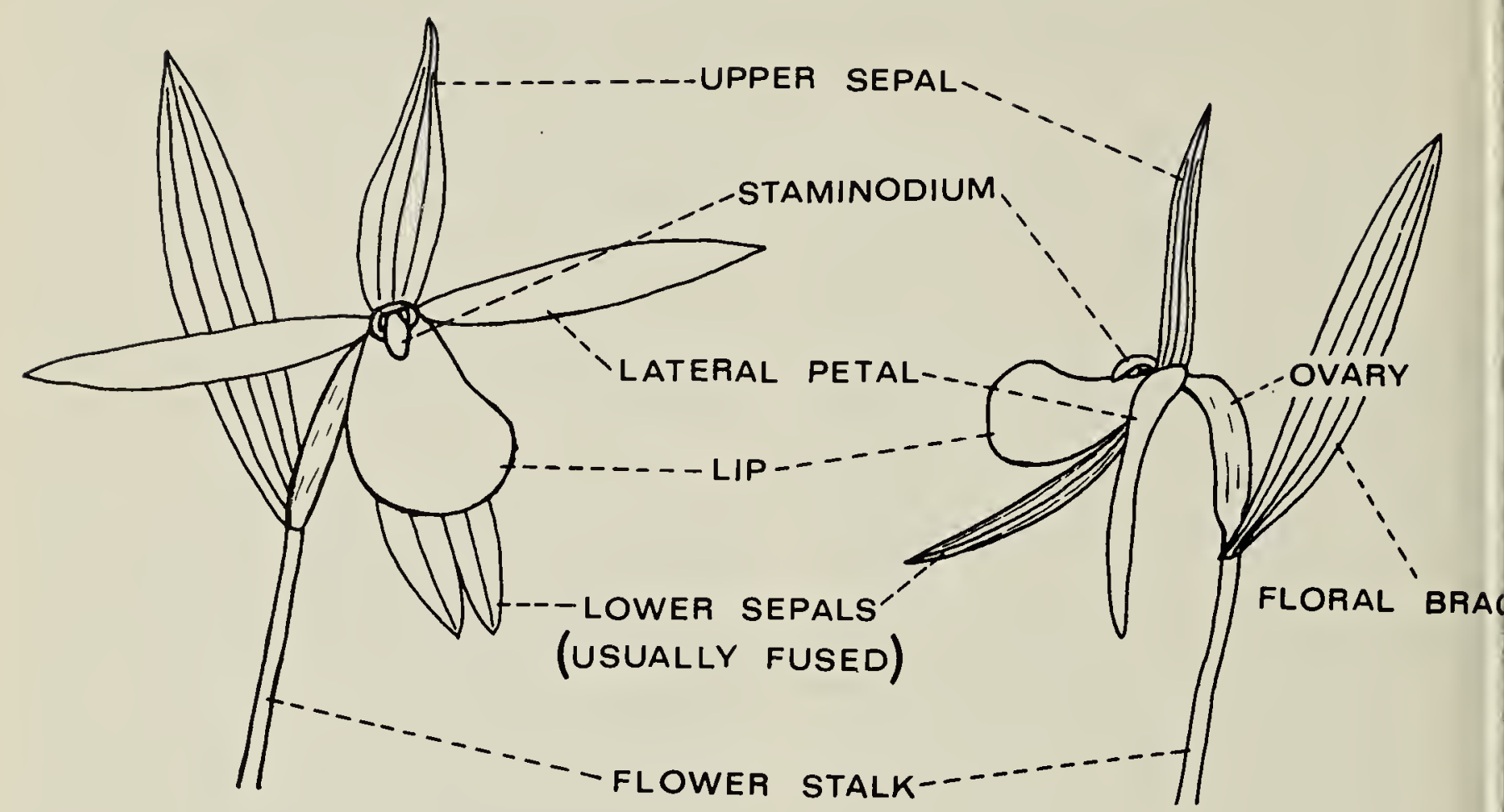

Figure 1. Parts of a lady's-slipper flower

number two leads. If the choice is the first of these leads, the identity of the unknown plant is the Yellow Lady'sslipper. If, instead, the choice is the second of these number two leads, the user goes on to a choice between the number three leads which will give him the species' identification.

The four lady's-slippers of Saskatchewan are illustrated in Figure 2, and their known distributions in Saskatchewan are shown in Figure 3 . The locality records shown in Figure 3 a derived from literature reports ar from locality data on specimens file in the W. P. Fraser Herbariun University of Saskatchewan, Saskatoc (SASK); the Biology Department He barium, University of Saskatchewa Regina (USAS); the Saskatchewa Museum of Natural History, Regir (DAS); the Department of Agricultu Herbarium at Swift Current (SCS); th Plant Research Institute, Departme

\section{IDENTIFICATION KEY TO THE LADY'S-SLIPPER ORCHIDS OF SASKATCHEWAN}

1. Flowering stem leafless except for two basal leaves and the floral bract; li pink with red veins, cleft (fissured) down the front.

$\ldots \ldots \ldots \ldots \ldots \ldots \ldots \ldots$ (1) Stemless Lady's-slipper (C. acaule

1. Flowering stem with alternating leaves nearly to the top; lip not cleft, but wit a rounded opening near the base.

2. Lip yellow

(2) Yellow Lady's-slipper (C. calceolus

2. Lip white, pink, or pale purple.

3. Lip white or pinkish-white, strongly purplish veined, inflated at the base an prolonged downward at the tip into a blunt, conical spur-like pouch; al three sepals free ........ (3) Ram's-head Lady's-slipper ( $C$. arietinum)

3. Lip white or pale purple with purple spots, less strongly veined, broadl rounded at the tip; the two lower sepals partly or entirely united

(4) Northern Lady's-slipper (C. passerinum) 
Agriculture, Ottawa (DAO); and the ational Museum of Canada, Ottawa AN).

\section{(1) Stemless Lady's-slipper.} ypripedium acaule Ait. The flowering ems are 4 to 12 inches to, rarely, 24 ches high, hairy, leafless except for e floral bract and two basal leaves. he two basal leaves are narrowly liptical to egg-shaped, sparsely hairy, to 8 inches long, pale beneath. The pral bract is lance-shaped, arching rward over the solitary terminal wer. The sepals are 1 to 2 inches ng, lance-shaped, yellow-green aded with purple, with the lower two als united and located under the - The lateral petals are 1-2 inches hg, lance-shaped, greenish-brown to llowish-green, flat or slightly isted. The lip is 1 to 3 inches long, g-like, drooping, with a cleft down front, pink with red veins.

This species is sometimes also called

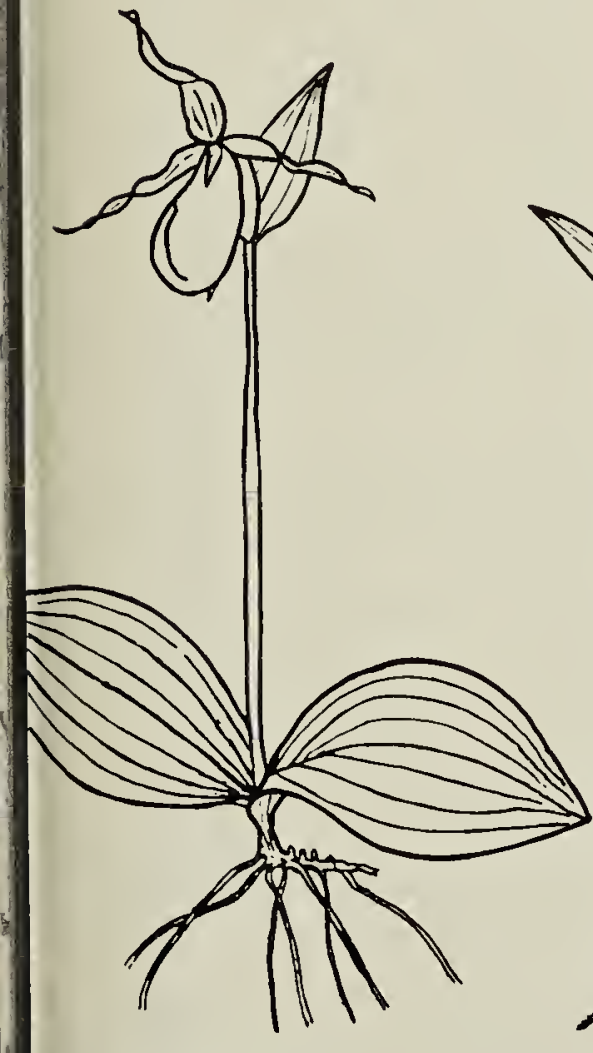

STEMLESS

LADY'S-SLIPPER

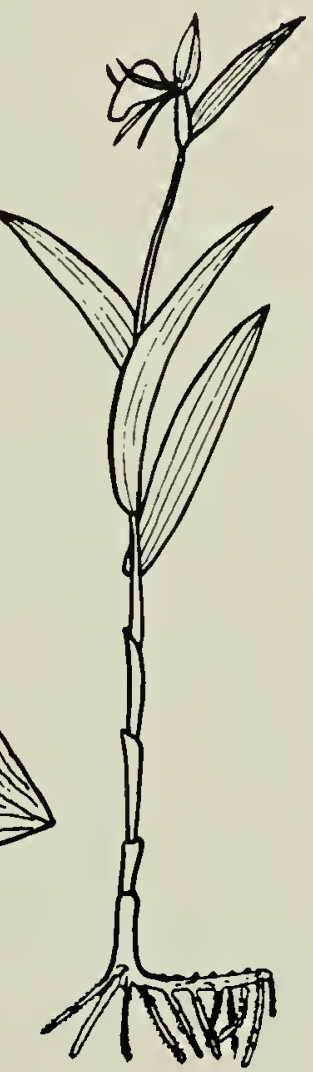

RAM'S-HEAD LADY'S-SLIPPER the Moccasin Flower or Nerve Root. In Saskatchewan, this is a boreal forest species, apparently found only in the northern half of the province. It is most often found on sandy soil under Jack-pine woods, but it has also been collected under both aspen and spruce woods. In Saskatchewan, the species is rare and thus far is known only from Lake Athabasca, Cree Lake, Lac Ile-ala-Crosse, 36 miles north of Green Lake, Pelican Narrows, Lac la Ronge, and from 15 to 70 miles north of $\mathrm{La}$ Ronge there are specimens from Cycloid Lake, Lynx Lake, MacKay Lake, Otter Rapids and Bervin Lake. The flowers bloom in June and July.

\section{(2) Yellow Lady's-slipper.} Cypripedium calceolus L. var. pubescens (Willd.) Correll (including C. parviflorum Salisb.). Stems 5 to 15 to rarely 25 inches tall, sparsely hairy and glandular, bearing 3 or 4 more or less sheathing leaves up and down the
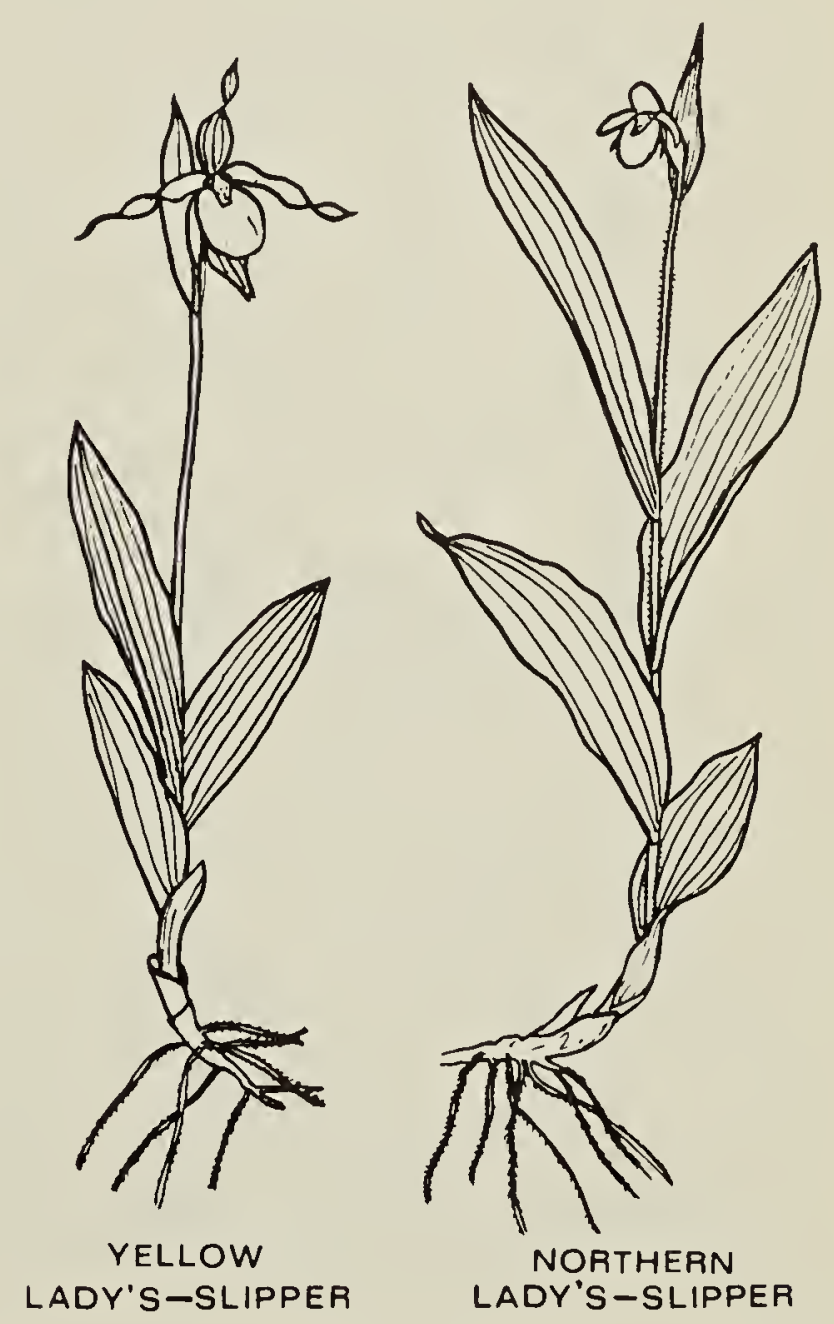

Ire 2. The four Saskatchewan lady's-slippers 
stem. The leaves are broadly elliptic, egg-shaped, or lance-shaped, pointed, 2 to 8 inches long and about half as wide, sparsely hairy and usually glandular. The large, terminal flowers are single or, rarely, two, each subtended and usually exceeded by an erect, leaflike floral bract. The sepals and lateral petals are greenish-yellow to purplishbrown. The upper sepal is broadly lance-shaped, 1 to 3 inches long; the lower sepals are somewhat narrower, united under the lip to sometimes almost distinct. The lateral petals are narrowly lance-shaped, 1 to $3-1 / 2$ inches long, wide-spreading, flat or usually somewhat twisted. The lip is inflated, pouch-shaped, rounded at the top with a rounded opening near the base, 1 to $2-1 / 2$ inches long, yellow and often purple-spotted near the basal opening.

This species is sometimes also called the Golden Slipper, Whip-poor-will Shoe or Moccasin Flower. In Saskatchewan, this species occurs mostly under moist aspen and other woods in the southern half of the province. It has also been collected occasionally on moist low spots in prairie areas. The Yellow Lady's-slipper has apparently not yet been collected in the northern half of the province north of the Lac La Ronge site, nor in southwestern Saskatchewan. The flowers bloom in June and July. It is the most common and abundant lady's-slipper in Saskatchewan. Plants with shorter sepals (under 2 inches), shorter lateral petals (under 2 inches), a smaller lip (under $1-1 / 4$ inch long), and narrower leaves (less than 2-1/2 inches wide) have often been separated as variety parviflorum (Salisb.) Fern. or even as a separate species, C. parviflorum, but these are now usually regarded as only an ecological form of wetter and colder habitats which is not worth distinguishing taxonomically.

(3) Ram's-head Lady's-slipper. Cypripedium arietinum $\mathrm{R}$. Br. The stems are slender, 4 to 15 inches tal thinly hairy, with 2 or 3 sheathir scales below and 3 to 5 leaves abov the middle. The leaves are lanct shaped to elliptic, often folded, 2 to inches long, smooth except for som fine marginal hairs. The flowers ar solitary and terminal. The sepals an lateral petals are $1 / 2$ to 1 inch lon greenish-brown to somewhat purplis All three sepals are distinct. The upp sepal is broadly lance-shaped; th lower sepals are narrower and more less twisted. The lateral petals at narrowly lance-shaped. The lip whitish, strongly purplish-veined, 1 to $3 / 4$ inch long, irregularly triangula prolonged downward at the tip with yellowish-green, blunt, conical, spu like pouch.

In Saskatchewan, the Ram's-hea Lady's-slipper was, until very recentl known only from Prince Albert, base upon two undated specimens collecte by $\mathrm{O}$. C. Furniss which are filed in th Fraser Herbarium. Recently, W. Cody (in the Blue Jay 31 (3): 180-18 September, 1973) reported i rediscovery a few miles northwest Prince Albert by $\mathrm{Mr}$. and Mrs. And Rosent. Even more recently, Mr. Fel ton $\mathrm{R}$. Vance (in a letter dated O tober 23, 1973 to the Blue Jay) repo ted sighting and photographing th species from near the town site of Huc son Bay. I have examined th photograph and it is indeed the Ram' head Lady's-slipper. Subsequently specimen from Hudson Bay was giv to us by Bernard de Vries and filed the Fraser Herbarium. Thes specimens were found in mid-June sandy soil under a stand of Jack-pir woods. This is an eastern species whic reaches its westernmost range limit Saskatchewan. Elsewhere, it general occurs on moist acid soils coniferous woods and blooms in $\mathrm{M}_{\mathrm{c}}$ or June.

(4) Northern Lady's-slippe Cypripedium passerinum Richards. $\mathrm{TH}$ 
ISTRIBUTION IN SASKATCHEWAN

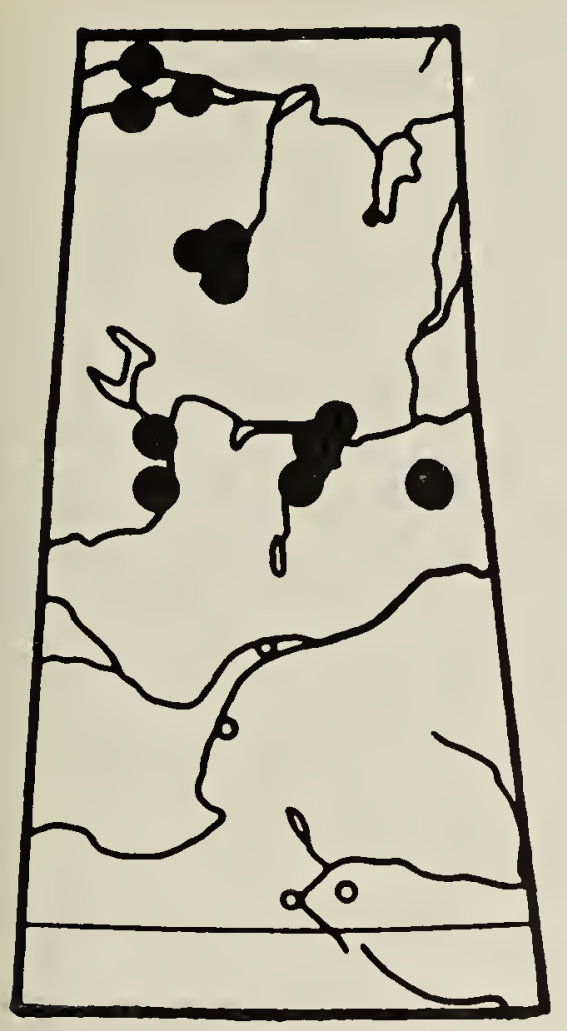

STEMLESS ADY'S-SLIPPER

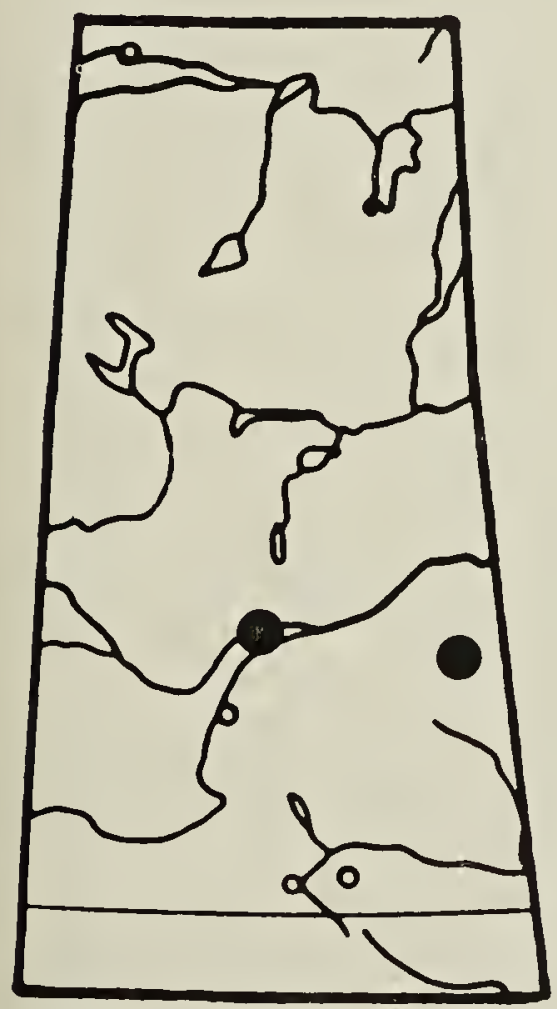

RAM'S - HEAD

ADY'S-SLIPPER

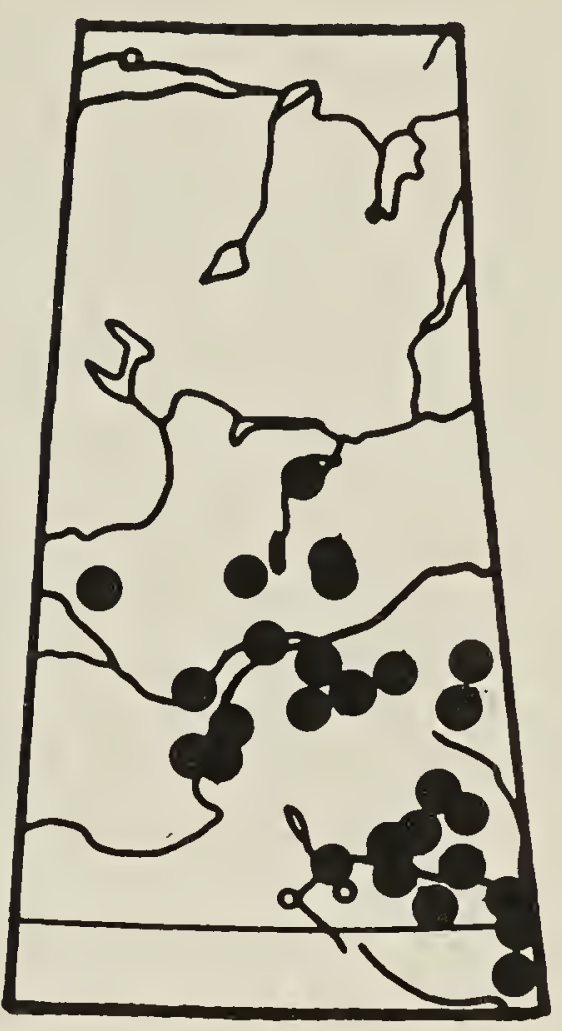

YELLOW LADY'S - SLIPPER

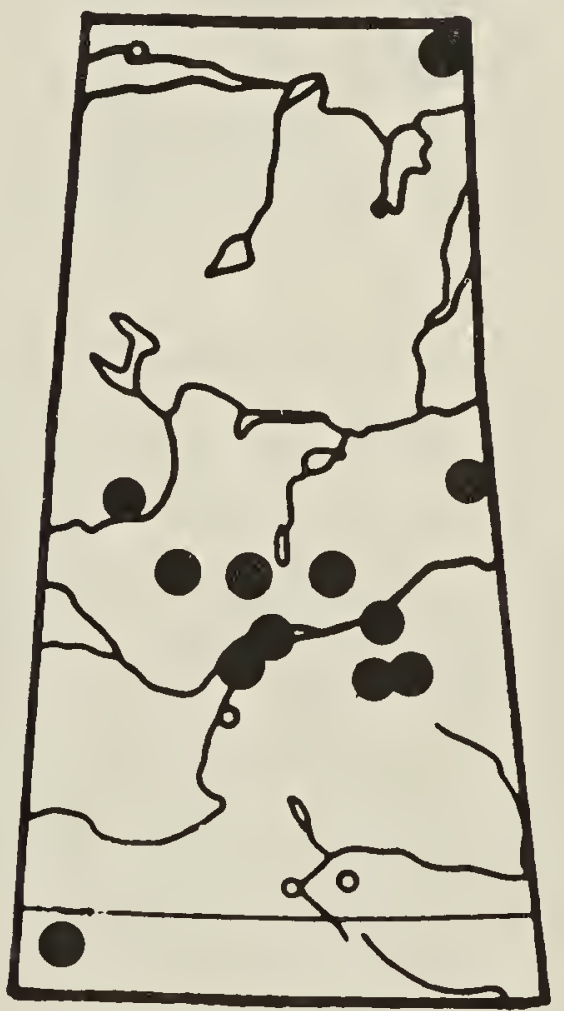

NORTHERN LADY'S-SLIPPER 
stems are 6 to 14 inches tall, quite densely hairy, and leafy throughout. The leaves are broadly lance- to eggshaped, $2-1 / 2$ to 8 inches long, $1 / 2$ to 2 inches broad, hairy and glandular. The flowers are relatively small, usually single, but occasionally 2 or 3 , exceeded by a large green floral bract. The upper sepal is green, broad, usually rounded or blunt at the tip, about $1 / 2$ inch long. The lower pair of sepals are also green, somewhat shorter, either completely united or almost distinct. The lateral petals are white, broad, blunt or rounded at the tip, about $1 / 2$ inch long. The lip is eggshaped, $1 / 2$ to $3 / 4$ inch long, white or pale lilac with reddish-purple spots on the inside.

\section{A SECOND SASKATCHEWAN RECORD FOR THE RAM'S-HEAD LADY'S-SLIPPER}

by BERNARD de VRIES*

Reference to the rediscovery of the Ram's-head Lady's-slipper, Cypripedium arietinum R. Br. (Sub Criosanthes arietina ( $\mathrm{R} . \mathrm{Br}$.) House), in Saskatchewan has been made by Cod $y^{2}$. Since publication of that paper, this orchid has also been reported from Hudson Bay in east-central Saskatchewan". This location is particularly noteworthy, as it constitutes a second record for Saskatchewan (Cody, personal communication, $7 / 1 / 74)$.

The present author had the opportunity to visit this location on June 15 , 1973, and found several well established populations in a forest type best described as the consociation

*Fort Qu'Appelle Herbarium, Fort Qu'Appelle, Saskatchewan. SOG ISO
This species is sometimes also calle the Sparrow-egg Lady's-slipper Small White Lady's-slipper. Althoug the species occurs in Saskatchewa from the Cypress Hills in the southwe: to Hasbala Lake in the northeaster corner of the province, it is relativel rare. Most collections are from spruc woods and bogs in the southern part the boreal forest area in the centr part of the province. In Saskatchewar the species is known from the Cypres Hills, Lake Waskesiu, MacDowal Bjorkdale, Prince Albert, Duck Lak McKague, Candle Lake, Nipawir Amisk Lake and Hasbala Lake. Th plants bloom from late June to earl August.

Pinetum banksianii. Recognized withi this consociation are limited strata edaphic socieities, with such species a Lyre-leaved Rockcress (Arabis lyrata) Bluets (Houstonia longifolia), Roc Selaginella (Selaginella rupestris) an Reindeer-moss (Cladonia spp.).

The collection station lies within th southern section of the boreal parkland transition zone of east central Saskatchewan. For a ful description of the Hudson Bay are and regional climate, reference can $b$ made to Breitung, Thomas, and Ken drew and Currie. ${ }^{1}+3$

The Saskatchewan localities are: few miles northwest of Prince Alber A. Rosent, May, 1972; a few mile southwest of Hudson Bay, B. de Vries June 15, 1973. No. 195.73. Vouche specimens are in the Vascular Plan Herbarium, Biosystematics Researcl Institute Research Branch Agriculture Canada, Ottawa (D MacPhedran, photo, $\left.\operatorname{Cod}^{2}\right)$, the W.P Fraser Herbarium, University o Saskatchewan, Saskatoon (O. C. Fur niss, first authentic report for Saskat chewan, $\left.\operatorname{Cod} y^{2}\right)$, and in the For Qu'Appelle Herbarium (No. 195.73). 